\title{
MONITORING URBAN GROWTH PATTERN OF DELHI USING REMOTE SENSING AND GIS TECHNIQUES
}

\author{
Rupesh Kumar Gupta \\ Assistant Professor, Dr. Bhim Rao Ambedkar College, University of Delhi, Delhi, India \\ Email: gisrs2004@gmail.com
}

\begin{abstract}
This research is focused on the land use land cover changes and urban expansion in megacity; Delhi, and highlights the major impact of the rapid growth of population and urbanization on the LULC changes for the period of thirty-four years, which need immediate attention. The multi-temporal satellite data and visual interpretation methods were used through Arc GIS Software. The results show that the built-up land has increased by $14.41 \mathrm{~km}^{2} /$ annum whereas agricultural, waste, barren and scrub land shrink by $9.59 \mathrm{~km}^{2} /$ annum, $4.29 \mathrm{~km}^{2} /$ annum respectively, during this period. The built-up area expanded from $298 \mathrm{~km}^{2}$ to $773.59 \mathrm{~km}^{2}$ during 1985 to 2018 on the cost of agricultural, waste, barren, and scrub land. The increment of forest 2.92 percent during this period shows a healthy sign. The findings would provide insight to the planners and policy makers; for the management of urban land, and problems related with the growth of city regions.
\end{abstract}

Key words: Urban Growth, LULCC, Built-Up Area, GIS, Remote Sensing

\section{Introduction}

Urbanization is one of the most important global change processes. As the share of people in, and the footprint of, urban areas continue to grow globally and locally, understanding urbanization processes and resulting land use both their patterns and intensity is increasingly important with respect to natural resource use, sociodemographics, health, and global environmental change (Seto and Reenberg, 2014). For decades, urban studies have been grappling with the question of how to define "urban"; the definition of urban includes comparatively straightforward official definitions, such as those that use the administrative unit with a set minimum number of inhabitants (Mclntyre et al. 2000 ), but, in some cases, it also includes such factors as population density, builtup area (urban landscape), commuting density, travel distance (Nilsson et al. 2014), and proportion of workforce engaged in non-agricultural economic activities (Census of India 2011).

Urbanization has been a megatrend of global land-use change that can be observed in all parts of the world. By 2050 close to 70 percent of the global population will live in cities (Eurosat,2016). The present trend of the urbanization in developing countries is especially due to rural-urban migration, the geographic expansion of urban areas through annexations, and the transformation and reclassification of rural villages into small urban settlements (United Nations, 2017). As has been observed in the rest of the world, India had similar impacts of urbanization and land use land cover (LULC) change. The independence of the country gave further impetus to the urbanization in Indian cities such as Delhi, Mumbai, Kolkata and Chennai (Delhi Census Handbook 1991). The economic liberalization policy of 1991 opened up the Indian economy to the international market, which saw incoming of a large share of foreign direct investment (FDI) in 
metropolitan cities. Delhi region received a maximum share of FDI compared to other regions of the country. Along with this allowance of 100 percent, FDI in real estate and infrastructure by the Indian government has made Delhi susceptible to rapid urban growth (Namperumal et al. 2011).

Delhi is one of the many megacities struggling with rapid urbanization and gigantic levels of pollution from industrial, residential and transportation sources (Mohan et al.2007). After independence, when Delhi witnessed a large influx of migrants, within a very short time the population of Delhi was approximately doubled. In a large migrating population, the city has expanded in a very unplanned and uncontrolled manner (Rahman, 2007). Such types of unplanned expansions have a direct impact on the quality of the urban environment affecting the efficiency of the people and their productivity in the overall socio-economic development (Netzband and Rahman,2007). In light of its past experiences and current trends of development, the emerging future of Delhi is one of the most important issue gaining focus from the authorities to improve the overall quality of life. Land use which is a highly dynamic entity in nature is one of the key parameters to quantify development (Gupta, 2014, 2006). The dynamic land-use database has a vital application to many diverse fields like Biodiversity-Environment, Forestry, Hydrology, Agriculture, Geology, Urban sprawl, etc.,

\section{Location of the Study Area}

The present study has been carried out on Delhi, the capital city of India located between the $28^{\circ} 24^{\prime} 17^{\prime \prime}$ and $28^{\circ} 53^{\prime} 00^{\prime \prime} \mathrm{N}$ latitudes and $76^{\circ} 45^{\prime} 30^{\prime \prime}$ and $77^{\circ} 21^{\prime} 30^{\prime \prime} \mathrm{E}$ longitudes. The elevation of the city ranges between 213 and $290 \mathrm{~m}$. Delhi, the National Capital Territory situated near the western bank of river Yamuna which spreads over an area of around $1,490 \mathrm{~km}^{2}$ is surrounded by the Himalayas in the North and the Aravali ranges in SouthWest. Delhi is one of the fastest-growing cities in the country. Due to the rapid pace of urbanization, the landscape of Delhi has undergone a change from a rural majority to urban. Delhi has 11 districts with 33 Tehsils/Sub-Divisions.

\section{Research Question}

The purpose of the study is to evaluate the impact of the rapid growth of population on the land use/land cover. To see the spatial pattern of land use/ land cover change over the last 34 years. It is also interesting to investigate the land transformation of different category. The study area witnessed of high population growth over the time periods, and the area drastically changes in last two decades. The horizontal growth of different landuse categories was evaluated through satellite data.

\section{Methodology}

The work has been based on census and satellite data, map sheets and village maps. The data has been processed through Arc-GIS software. The data collection involved satellite Image, secondary published data and limited primary data. To understand the complexity of dynamics of the pattern of land-use change of the city and land transformation, a few indicators were examined. The indicators such as land use, roads, railway network and the agricultural area were captured from map sheets and imagery and each of the layers were digitized. The extension of agriculture land during the last four decades (1985-2018) is determined by computing the area from the digitized map sheets, imagery and compared it with the areas of different time periods. The land use classification is shown in Table-1. To find out the growth of the city and its built-up area; we used Google Earth Image data with limited ground truth verification, Survey of India data, topo sheets, Other data: Census of India 1981,1991, 2001 \& 2011, Planning Commission, Master Plan 2001, 2021 of DDA etc. other Ancillary Data provided basic information of the study area. With the help of topographic map $(1: 50,000)$, we prepared a base map of the study area, and then rectified all data through base map and proceed for visual classification (figure 1). 
Table 01: Land Use Classes Considered in Image Classification

\begin{tabular}{|l|l|}
\hline Land use class & General description/Subclass \\
\hline Built-up Land & $\begin{array}{l}\text { Include Dense, Moderate, Sparse as well as Rural settlements, } \\
\text { Industrial, Institutional, Commercial, Recreational, Transportation } \\
\text { and utilities. }\end{array}$ \\
\hline Agricultural Land & Cropland, Fallow land \\
\hline Forest & Trees, green cover, Plantation \\
\hline Wasteland & Scrub land, Water logged, hills / barren rock \\
\hline Water Bodies & River, Pond, tank/lakes \\
\hline $\begin{array}{l}\text { Transport } \\
\text { Network }\end{array}$ & $\begin{array}{l}\text { Railway, Metro Rail, Expressway, National Highway, Major and } \\
\text { Minor Road }\end{array}$ \\
\hline
\end{tabular}

Source: prepared by Author

Figure 01: Methodology Chart

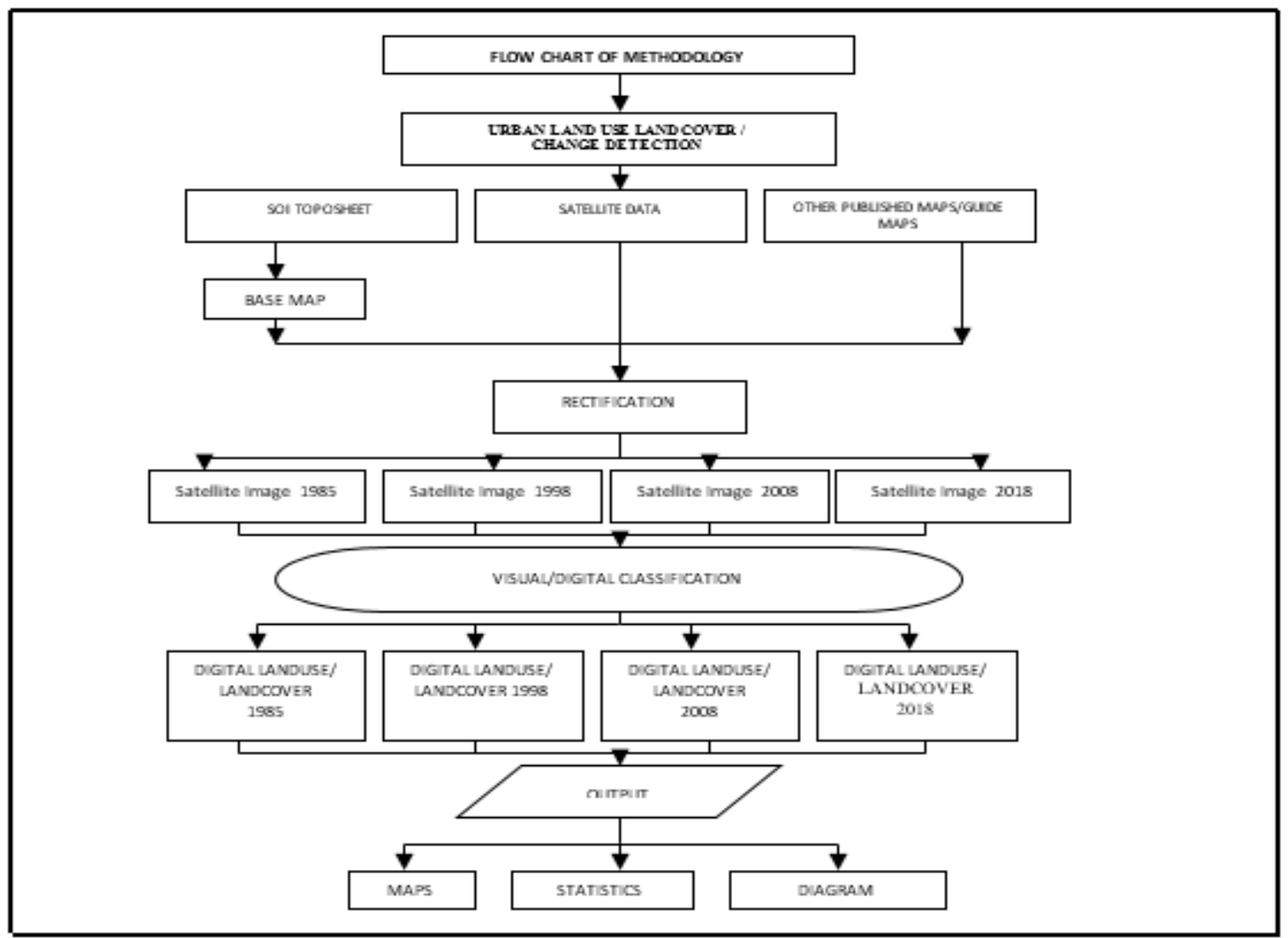

Source: prepared by Author

With the help of Arc GIS software, we completed visual classification and remove all error like undershoot, overshoot as well as removed some error through reference map and field visit. The spatial framework of GIS database was organized in GIS as per the topographical maps coordinates and projection system. A grid was generated in ArcInfo with four-tic points for each map/sheet covering entire NCT Delhi Area. All these layers of different time periods were transferred to the above grid for commonality. Thematic map drafts were prepared on a sheet-by-sheet basis for digitization. On each sheet, all the required themes were drawn (all land use categories-different road, and built-up land). Four different time period land use maps (1985, 1998, 2008 \& 2018) were prepared on the basis of Image data (figure 1). 


\section{RESULT AND DISCUSSION \\ Population Growth in Delhi}

As per this census, the population of Delhi, as of 1st March 2011, was 16.78 million as against 13.85 million on 1st March 2001. According to Census 2011, about 97.50 percent of the population of Delhi lives in urban areas and the remaining 2.5 percent in rural areas. The total population of Delhi was nearly 0.4 million in 1901, which increased slowly and reached 1.74 million in 1951 (4.35 times in half-century) and 13.78 million in 2001 (census of India, 2001) implying about 34.45 times increase in one century. As per this census, the population of Delhi, as of 1 st March 2011, was 16.78 million as against 13.85 million on 1st March 2001.

The growth in the urban area during 2001-2011 was observed at 20.44 percent. This pace of urbanization has reduced the number of villages in Delhi from 300 in 1961 to 165 in 2001 and 112 in 2011. The number of urbanized villages has increased from 20 in 1961 to 135 in 2011. The number of census towns has increased from 3 in 1971 to 29 in 1991 and 110 in 2011.The decadal growth rate of the population during 2001-2011 was recorded at 21.2 percent. This is a peculiar feature of Census 2011, as in all censuses since 1951, the decadal growth rate of the population was more than 50 percent and 47 percent in 2001 (Table $2 \& 3$, figure 2). The sequence of growth through the four phases, particularly the present day phase has set the base for the growth dynamics of the city. The growth has been analyzed taking both the demographical dynamics of the city as well as areal dynamics of the city. The demographic structured much more changes in Delhi for the last 110 years. If we go through the following data (Table-2, figure 2), it seems that the population of Delhi increased more than forty-one fold during 1901-2011.

Phase 1. 1901-1941-low to medium growth- during this period the growth rate was slow and after that, the decadal growth was from 1.98 to $18.03,30.26$ and 44.27 percent during 1901-1941. It may be the cause of shifting of British Indian Capital from Calcutta to Delhi in 1931. The announcement made in 1911 and name of New Delhi declared 1927 and capital inaugurated on 13 February 1931. The population grew rapidly from 4.13 lakh to 9.17 lakh from 1911 to 1941.

Phase 2. Very high growth rate-during 1941 to 1951, the decadal growth rate was 90 per cent, this is a very high growth rate ever in Delhi. All this happened due to India got independence and country divided in two-part, so most of the people attracted towards Delhi, and that's the reason for the suddenly highest growth of population.

Table 02: Decadal Population Growth \&Trend of Urbanization in Delhi: 1901-2011

\begin{tabular}{|c|c|c|c|c|c|c|}
\hline $\begin{array}{c}\text { Census } \\
\text { Year }\end{array}$ & $\begin{array}{c}\text { Total } \\
\text { Population }\end{array}$ & $\begin{array}{c}\text { Percentage } \\
\text { Decadal } \\
\text { Growth }\end{array}$ & $\begin{array}{c}\text { Average } \\
\text { Annual } \\
\text { Exponential } \\
\text { Growth }\end{array}$ & $\begin{array}{l}\text { Total Urban } \\
\text { Population }\end{array}$ & $\begin{array}{l}\text { Total } \\
\text { Urban } \\
\text { Area } \\
\text { (sq. km.) }\end{array}$ & $\begin{array}{l}\text { Percent } \\
\text { Urban } \\
\text { Population }\end{array}$ \\
\hline 1901 & 405,819 & - & - & 214115 & - & 52.76 \\
\hline 1911 & 413,851 & 1.98 & 0.20 & 237944 & 43.25 & 57.50 \\
\hline 1921 & 488,452 & 18.03 & 1.67 & 304420 & 168.09 & 62.32 \\
\hline 1931 & 636,246 & 30.26 & 2.68 & 447442 & 169.44 & 70.33 \\
\hline 1941 & 917,939 & 44.27 & 3.73 & 695686 & 147.31 & 75.79 \\
\hline 1951 & $1,744,072$ & 90.00 & 6.63 & 1437134 & 201.36 & 82.40 \\
\hline 1961 & $2,658,612$ & 52.44 & 4.31 & 2359408 & 326.55 & 88.75 \\
\hline 1971 & $4,065,698$ & 52.93 & 4.34 & 3647023 & 446.26 & 89.68 \\
\hline 1981 & $6,220,406$ & 53.00 & 4.34 & 5768200 & 540.78 & 92.73 \\
\hline 1991 & $9,420,644$ & 51.45 & 4.24 & 8471625 & 685.34 & 89.93 \\
\hline 2001 & $13,850,507$ & 47.02 & 3.93 & 12905780 & 924.68 & 93.18 \\
\hline 2011 & $16,787,941$ & 21.21 & 1.94 & 16368899 & 1113.65 & 97.50 \\
\hline
\end{tabular}

Source: Census of India 2001, 2011, Economic Survey of Delhi: 2008-2009 
Figure 02: Growth of Population of NCT Delhi (1901-2011)

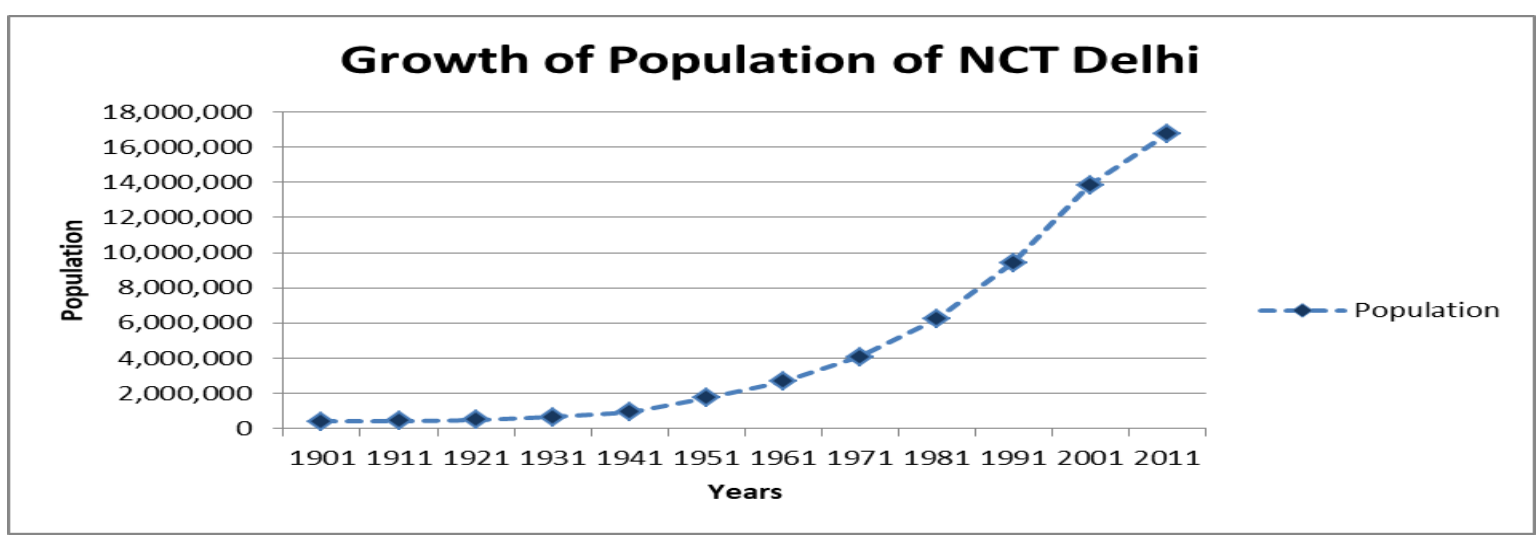

Source: Census of India 1991, 2001, and 2011

Phase 3. High Growth Rate during 1951-1991-in this phase the population growth is high, and the decadal growth was more than 50 percent. Due to development of health sector, the birth rate was high but the death rate continues decline, resulting in a high growth of population. The other factor was the migration of population from other states to Delhi is to search for Job Opportunities, career advancement, safety-security and a better life.

Phase 4. Slowly decline growth rate during 1991-2020-in this period the decadal growth rate below 50 percent, it was 47.02 percent in 2001 and 21.21 percent in 2011. The decline of growth rate only causes of education, awareness among people, singlefamily system, job opportunity, urbanization, urban lifestyle, and high and expensive living standard of the people of urban area.

Table 03: Estimates of Natural Growth and Migration in NCT Delhi: 1991-2016 (Figures in lakh)

\begin{tabular}{|c|c|c|c|c|c|c|}
\hline Year & $\begin{array}{c}\text { Estimated Mid- } \\
\text { Year Population }\end{array}$ & $\begin{array}{c}\text { Annual } \\
\text { Increased } \\
\text { Population }\end{array}$ & $\begin{array}{c}\text { Total } \\
\text { birth }\end{array}$ & $\begin{array}{c}\text { Total } \\
\text { Death }\end{array}$ & $\begin{array}{c}\text { Natural } \\
\text { increase }\end{array}$ & $\begin{array}{c}\text { Increase } \\
\text { due to } \\
\text { migration }\end{array}$ \\
\hline 1991 & 95.50 & 3.89 & 2.72 & 0.61 & 2.11 & 1.78 \\
\hline 1994 & 107.50 & 4.12 & 2.62 & 0.68 & 1.94 & 2.18 \\
\hline 1997 & 120.57 & 4.47 & 2.89 & 0.71 & 2.18 & 2.29 \\
\hline 2000 & 134.60 & 4.78 & 3.17 & 0.80 & 2.37 & 2.41 \\
\hline 2001 & 139.50 & 4.90 & 2.96 & 0.81 & 2.15 & 2.75 \\
\hline 2004 & 152.79 & 4.36 & 3.06 & 0.85 & 2.21 & 2.15 \\
\hline 2007 & 156.45 & 2.98 & 3.22 & 1.01 & 2.21 & 0.77 \\
\hline 2010 & 165.74 & 3.16 & 3.59 & 1.24 & 2.35 & 0.81 \\
\hline 2011 & 168.96 & 3.22 & 3.53 & 1.12 & 2.41 & 0.81 \\
\hline 2014 & 179.00 & 3.41 & 3.74 & 1.21 & 2.53 & 0.88 \\
\hline 2016 & 186.01 & 3.54 & 3.79 & 1.42 & 2.37 & 1.17 \\
\hline
\end{tabular}

Source: Office of Chief Registrar, Births \& Deaths, Government of NCT Delhi

(Compiled from: Economic Survey of Delhi: 2008-2009 and Economic Survey 2017-18).

In 1951, there were 304 villages in Delhi, but in 2011 it reduced to stand 105, the rural area also reduced sharply along with rural population and it's almost around 300 $\mathrm{km}^{2}$. The major reason of migration from other states to Delhi may be the economic, social, political or better opportunities, infrastructure, technological advancement, law and order, social security, career security, good institution and good health Centre etc. (Table$3)$. 


\section{Land Use Land Cover Pattern}

For any comprehensive study of the growth of cities over time and space, it is not sufficient if a researcher examines only the general structure of the cities. Rather, it is essential to understand land use arrangement and the population patterns existing within them (Gupta \& Singh, 2012). For this purpose, the present study, the land use maps of 1985, 1998, 2008 and 2018 were prepared. The study covered almost a period of 35 years i.e., from 1985 onwards in the spatial pattern of land use and land cover.

\section{Land Use/Land Cover of 1985}

For the preparation of land use/land cover map, the boundary covered almost $1484 \mathrm{~km}^{2}$ and result of this much area show that out of the total area, cropped area was 47.50 percent, Fallow Land was 1.61 percent, Barren and Scrub land was 14.56 percent, the forest was 14.08 percent, the plantation was 3.62 and water bodies 2.15 percent respectively. Only 20.08 percent of the total study area was built-up land (Table 4, Figure $3, \& 4)$. In this period the rate of growth as well as, land transformation was slow. This shows that the area exhibits a low growth rate during this period.

\section{Land Use/Land Cover of 1998}

After the gap of thirteen years since 1985, the following changes occurred in land use categories, the crop land decline from 37.49 percent to 10.01 percent of its previous year 1985 due to utilization of cropland for settlement and commercial purpose or other requirements to meet the demands of this land. The fallow land decreased by 1.61 to 1.05 percent but the forest increased, from 14.08 to 14.25 percent respectively (Table 4, Figure 3, \& 4). The areal extent of Built-up land indicates that the development of the city during this period, which has occupied 31.88 percent of the total study area under builtup, comprises of high density (11.73 percent), medium density (6.89 percent), and low density (11.61 percent). 11.80 percent of the total area comes under land under transformation, thus indicating the developmental process of the city.

Table 04: Land Use Land Cover Area Statistics of 1985-2018

\begin{tabular}{|l|c|c|c|c|c|c|c|c|c|c|c|}
\hline \multirow{2}{*}{$\begin{array}{l}\text { Year/LULC } \\
\text { Category }\end{array}$} & \multicolumn{2}{|c|}{1985} & \multicolumn{2}{c|}{1998} & \multicolumn{2}{c|}{2008} & \multicolumn{2}{c|}{2018} & \multicolumn{1}{c|}{$\begin{array}{c}1985- \\
1998\end{array}$} & $\begin{array}{c}1998- \\
2008\end{array}$ & $\begin{array}{c}2008- \\
2018\end{array}$ \\
\cline { 2 - 13 } & $\mathrm{km}^{2}$ & $\%$ & Area & $\%$ & $\mathrm{~km}^{2}$ & $\%$ & $\mathrm{~km}^{2}$ & $\%$ & \multicolumn{2}{|c|}{ Growth km ${ }^{2}$ per annum } \\
\hline Built Up Land & 298 & 20.08 & 472.98 & 31.88 & 692.50 & 46.67 & 773.59 & 52.13 & 13.46 & 21.95 & 8.10 \\
\hline $\begin{array}{l}\text { Agricultural } \\
\text { Land }\end{array}$ & 729 & 49.12 & 572 & 38.54 & 485.91 & 32.74 & 412.41 & 27.79 & 12.07 & 8.60 & 7.35 \\
\hline Forest & 209.02 & 14.08 & 211.42 & 14.25 & 153.96 & 10.38 & 197.34 & 13.29 & 0.18 & 5.75 & 4.34 \\
\hline $\begin{array}{l}\text { Barren \& } \\
\text { Scrub Land }\end{array}$ & 215.98 & 14.56 & 196.31 & 13.23 & 121.55 & 8.19 & 74.23 & 5.01 & 1.51 & 7.47 & 4.73 \\
\hline Water Bodies & 32 & 2.16 & 31.29 & 2.10 & 30.08 & 2.02 & 26.43 & 1.78 & 0.05 & 0.12 & 0.36 \\
\hline Total Area & 1484 & 100 & 1484 & 100 & 1484 & 100 & 1484 & 100 & & & \\
\hline
\end{tabular}

Sources: based on multi temporal Satellite Data

\section{Land Use/Land Cover of 2008}

During 2008 the built-up land has grown from 31.88 percent to 46.67 percent registering an increase of 14.79 percent area of built-up land. During this period Agricultural Land shrink by 38.54 to 32.74 percent and the built-up area increased 14.79 percent respectively, which indicates the areal expansion of the city (Table 4, Figure 3 , \& 4). Another category like Fallow land has decreased from 1.05 percent (in 1998) to 0.74 percent (in 2008) due to utilization of fallow land for growing vegetables or converted into a new settlement. Similarly, crop area decreased by 7.3 percent.

\section{Land Use/Land Cover of 2018}

During 2008 to 2018 the high-density built-up land increased (31 percent) by around 461 $\mathrm{km}^{2}$ whereas the total built-up land reached $773.59 \mathrm{~km}^{2}$ within 10 years. In a little span of time, the land use rapidly changed especially in fallow land, waste or barren land, scrub 
land which was either converted into low or medium density settlement or urban slum. During this period most of the land converted into medium to high or low to high density (Table 4, Figure 3, \& 4). A large number of villages merged in the municipal area and lost their identity and living style. Ultimately it will change their ecology and environment of the surrounding.

Figure 03: Land Use Land Cover Map of 1985-2018

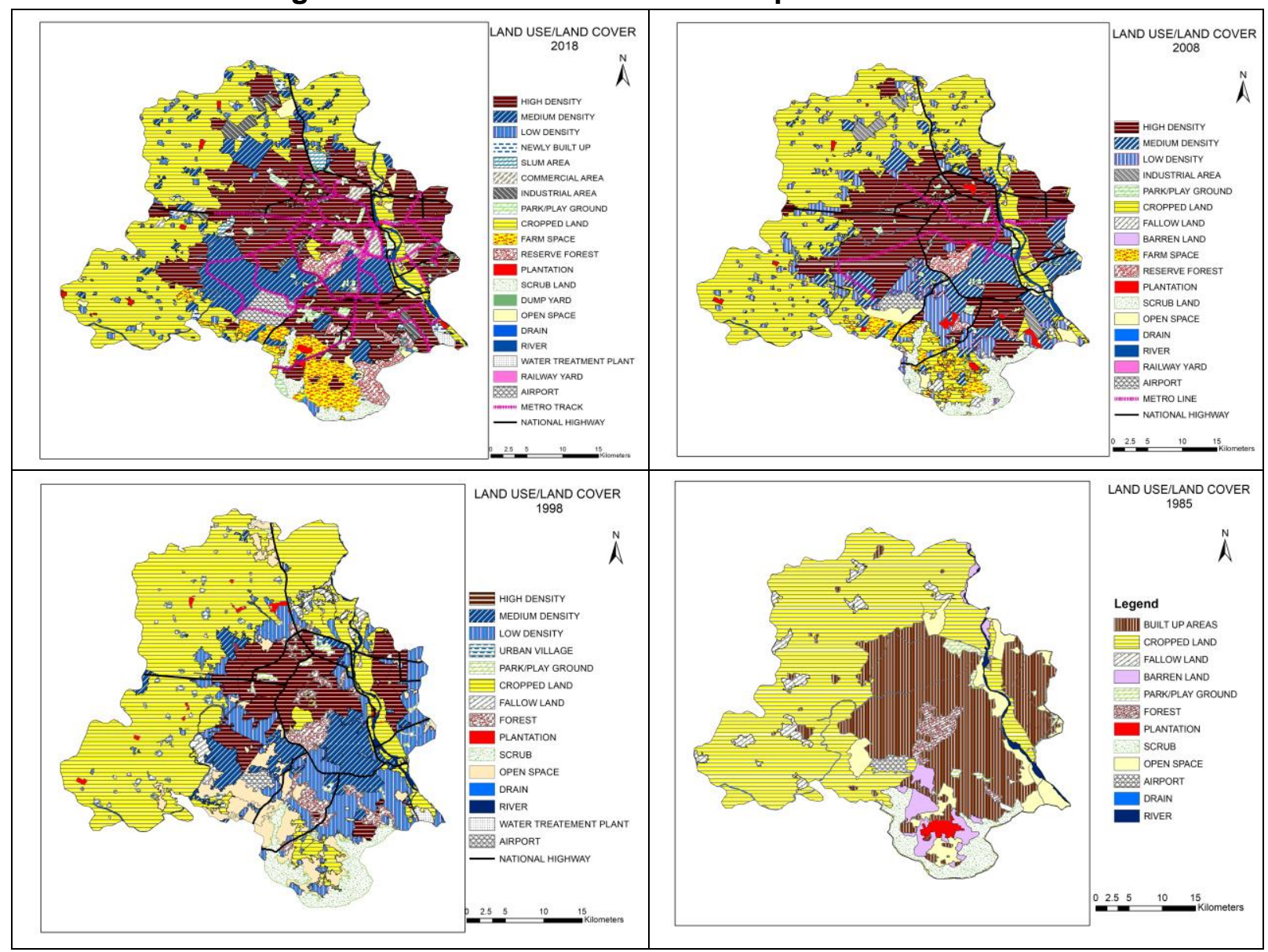

Sources: based on multi temporal Satellite Data

\section{Land Transformation and Change Detection}

In 1985, the Built-up land covered $298 \mathrm{~km}^{2}$ or 20 percent of the study area, where agricultural land stand with 49.12 percent, $209 \mathrm{~km}^{2}$ area covered by forest, $215.98 \mathrm{~km}^{2}$ area under scrub, waste and barren land, as well as water bodies stand with 2.16 percent of the area. The cropped area covered by 47.50 percent, whereas fallow land 1.61 percent, forest 10.46 percent, and plantation 3.62 percent respectively. In 1998, after the gap of 13 years, a massive change observed in this categories and built-up land rapidly increased to reached 31.88 percent of the study area, and agricultural land shrinks by $729 \mathrm{~km}^{2}$ to $572 \mathrm{~km}^{2}$, and forest slightly increased $209 \mathrm{~km}^{2}$ to $211 \mathrm{~km}^{2}$, waste-barren and scrub land stands with 13.23 percent (earlier in 14.56 percent) of the area, where water bodies have no major changes and it still stands on 2.16 to 2.10 percent respectively (Table 4, Figure 3, \& 4). The built up land comprises the high density built up area covered 11.73 percent, medium density 6.89, and low-density 11.61 percent. In 2008, after 10 years of gap, there was a major change seen in built-up land, and it covered 46.67 percent or $692.50 \mathrm{~km}^{2}$, where $372 \mathrm{~km}^{2}$ or 25.07 percent high density, $160.57 \mathrm{~km}^{2}$ or 10.82 medium, and $126.17 \mathrm{~km}^{2}$ or 8.50 percent low-density area, and this expansion is in the cost of agricultural land; which shrink from 38.54 to 32.74 percent, forest; 14.25 to 10.38 percent and waste-barren-scrub land; 13.23 to 8.19 percent, respectively. The change which has taken place during this period is mainly based on fallow land, cropped 
land, forest, barren and scrub land. The fallow and cropped land shrink by 37 to 30 percent, forest from 14.25 to 10.38 percent and degraded-waste-barren and scrub land shrink decreases by 13.23 to 8.19 percent area respectively (Table 4, Figure 3, \& 4).

In 2018, the rate of growth was slow, and the urban built-up area cover 773.59 $\mathrm{km}^{2}$ or 52.13 percent, in which high density built-up area increased by $372 \mathrm{~km}^{2}$ to 461 $\mathrm{km}^{2}$ or 25 to 31.45 percent, medium-density from $160.57 \mathrm{~km}^{2}$ to $181 \mathrm{~km}^{2}$ or 10.82 to 12.19 percent and low density decrease by 2 percent area. In the other side, the agricultural area shrinks by $485.91 \mathrm{~km}^{2}$ to $412.41 \mathrm{~km}^{2}$. The positive changes observed in the forest area, which extended from $153.96 \mathrm{~km}^{2}$ to $197.34 \mathrm{~km}^{2}$, which is almost 13.29 percent of the study area. Other categories of land like scrub, waste, barren continue decline from $121.55 \mathrm{~km}^{2}$ to $74.23 \mathrm{~km}^{2}$ which has almost 5 percent of the study area (Table 4, Figure 3, \& 4). The development of infrastructure and migration of people (Table-3) from a different state made it highly populated region and the explosive population growth (Table-2), created many problems, among them, the land use is prominent, which is challenging for the sustainability of urban ecology and environment of this region.

Figure 04: Land Transformations/ Change Detection Map of 1985-1998, 1998-2008, and 2008-2018

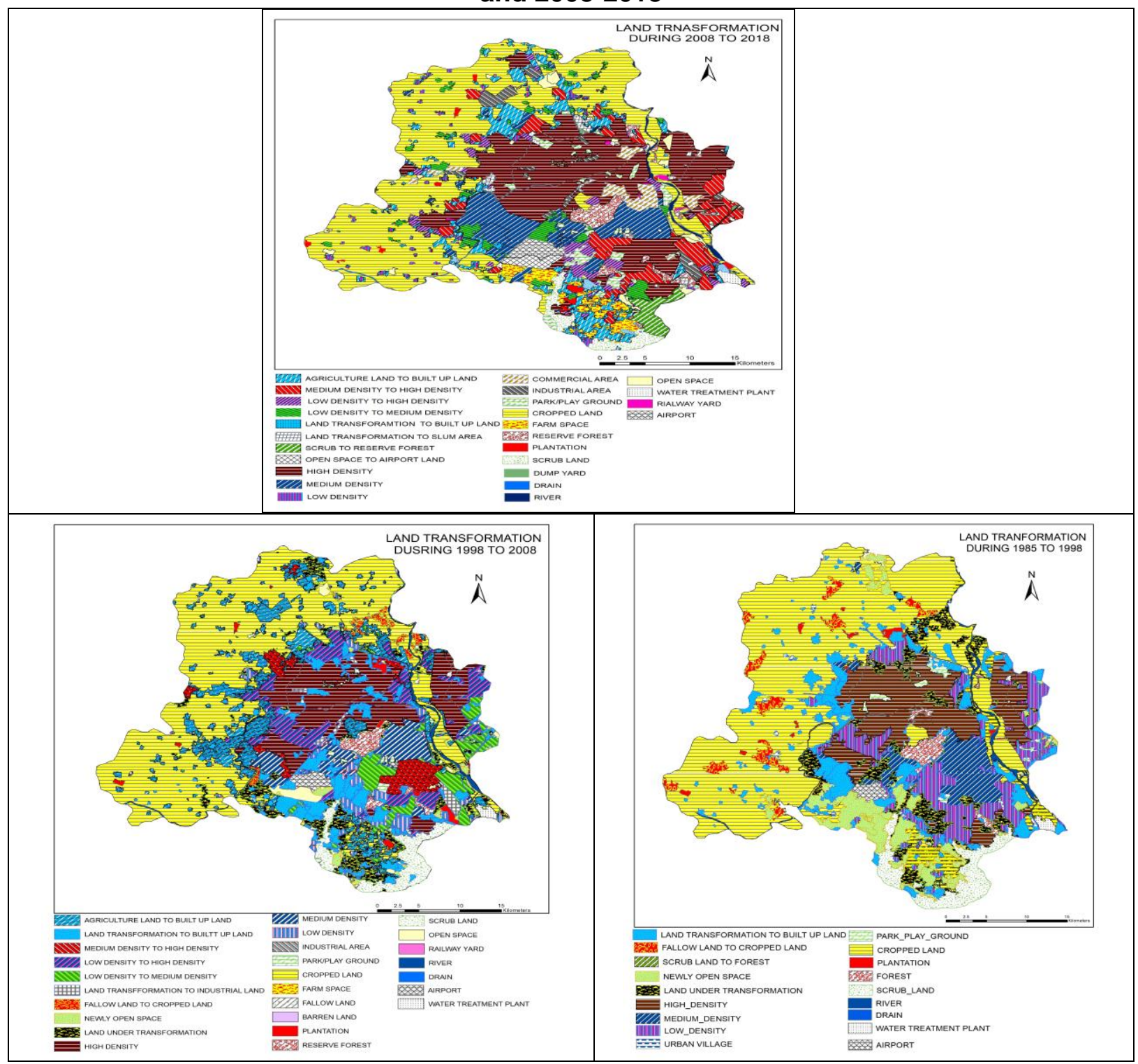

Sources: based on multi temporal Satellite Data 


\section{Major Finding and Conclusion}

Figure 3 and 4, depicts the land use pattern in and around of Delhi in 1985, 1998, 2008 and 2018 and Figure-4 shows the land-use changes during the last decade (1985-2018) which is still continuing. The urban villages in Delhi region can broadly be classified into three categories based on the process of their transformation: Rural - dominated with agricultural land and primary activities; urban slum and unauthorized colonies converted into urban built up, and transitional semi-rural to semi-urban dominated with built-up land and territory activities. Figure 3 \& 4 (urban land-use change 2008-2018, \& land use 2018) highlights the following:

- Major conversion of agricultural land into urban built-up: commercial, residential and institutional land. The built-up area is largely added in peripheral areas rather than along transit.

- The built-up land increased during 1998-2008 that is $21.95 \mathrm{~km}^{2} /$ annum, compared to $1985-1998$ (13.46 $\mathrm{km}^{2} /$ annum) and in 2008-2018 (8.10 $\mathrm{km}^{2} /$ annum). This is found that the most of the built-up area expanded during 1998-2008, on the cost of fallow, crop, barren and scrub land.

- Similarly, the agricultural land rapidly declines in the rate of $12.07 \mathrm{~km}^{2}$ per annum during $1985-1998,8.60 \mathrm{~km}^{2}$ in 1998-2008, and $7.35 \mathrm{~km}^{2}$ per annum in 2008-2018, respectively. The waste, barren and scrub land shrink by $1.51,7.47$, and $4.73 \mathrm{~km}^{2}$ per annum during this period.

- The open areas, greenery-forest and scrub land, agricultural-crop land, water body are more vulnerable due to land-use changes.

- The rapid population growth, urbanization, economic reform and development of physical infrastructure has triggered effect the land-use changes.

- The increase in population size has simultaneously led to the areal growth and spatial changes in the city thus, altering the landscape. Robust implantation strategies are required for sustainable intervention.

The rapid growth of population, migration and changing economy has major forces behind land-use changes in the city. The rapid population growth, created many problems like pollution, groundwater level decline, decreased green cover, and urban heat island etc. There is a requirement to developed infrastructure and services according to the thirst of the master plan of Delhi 2021 to cope with the demand for rapid growth. For the future point of view, to check the population, and try to encourage vertical growth instead of spatial, and the high rise building also opt the green roof to protect from heat during summer, it will help to address the problem of the urban area.

\section{References}

1. Census of India, $(1991,2001,2011)$. Delhi Census Handbook $(1991,2001)$ Directorate of census operations, Delhi http://www.censusindia.gov.in. New Delhi

2. Delhi Human Development Report (2006). Planning Commission of India, http://planningcommission.nic.in/plans/stateplan/sdr_pdf/shdr_del06.pdf.

3. Delhi Development Authority, The Master Plan for Delhi (1962, 2001 \& 2021).

http://dda.org.in/planning/mpd-1962htm

http://dda.org.in/planning/mpd-2001 htm

http://dda. org.in/planning/mpd-2021.htm

4. Eurosat (2016). Urban Europe. Statistics on Cities, Towns and Suburbs. Edited by European Commission. Luxembourg. Available online at: http://ec.europa. eu/eurostat/web/products-statistical-books/-/KS-01-16-691

5. Govt. of India. (1991, 2001,2011). Census of India, 1991, 2001 and 2011. Registrar General and Census Commissioner (1993), Census of India, (1991), Census of India, (2011). Census Atlas, Directorate of Census Operations, Government of India, New Delhi. http://censusindia.gov.in/ 
6. Govt. of India. (2010, 2018). Economic Survey of Delhi: 2008-2009 \& 2017-18, Economic Division, Ministry of Finance, Government of India, New Delhi.

7. Government of NCT Delhi (2017). Directorate of Economics \& Statistics (2017), Delhi Statistical Handbook, 2017, Directorate of Economics \& Statistics, Government of NCT Delhi, Delhi.

8. Government of NCT Delhi $(2009,2011,2018)$. Planning Department (2009), Economic Survey of Delhi, 2008-09, 2010-2011, \& 2017-2018, Planning Department, Government of NCT Delhi, New Delhi.

9. Government of NCT Delhi (2011). Office of Chief Registrar, Births \& Deaths, Government of NCT Delhi

10. Gupta, R. (2014). The Pattern of Urban Land Use Changes: A Case Study of the Indian Cities, Environment and Urbanization ASIA, Vol.5, No 1, pp 83-104. Sage Publication.

11. Gupta, R., Singh. R.B. (2012). Environmental Implications of Land Use Change in Jaipur City Using Satellite Data, Indian Journal of Regional Science, Vol. XXXXIV, No.2,2012 pp 141-154

12. Gupta, R. (2006). Study of Population Change and Urban Land Use relationship using an integrated Remote Sensing and GIS Approach, Deccan Geographer, Vol.44, Pp 1-12.

13. Mclntyre, N.E., Knowles-Yanez, K., and Hope, D. (2000). Urban Ecology as an Interdisciplinary Field: Differences in the Use of "Urban" between the Social and Natural Sciences, Urban Ecosystems, 4: 5-24.

14. M. Mohan, Lalit Dagar and B. R. Gurjar, (2007). "Preparation and Validation of Gridded Emission Inventory of Criteria Air Pollutants and Identification of Emission Hotspots for Megacity Delhi," Environmental Monitoring and Assessment, Vol. 130, 2007, pp. 323-339. doi:10.1007/s10661-006-9400-9

15. M. Netzband and A. Rahman, (2007). "Urban Remote Sensing for a Fast-Growing Megacity: Delhi, India," SPIE Inter- National Society Advancing an Interdisciplinary Approach to the Science and Application of Light, Berlin, Germany, 2007. http://spie.org/x17987.xml

16. Nilsson K., Nielsen T. S., Aalbers C., Bell S., Boitier B., Chery J-P, Fertner C., Groschowski M., Haase D., Loibl W., Pauleit S., Pintar M., Piorr A., Ravetz J., Ristimaki M., Rounsevell M., Tosics I., Westerink J., Zasada I. (2014). Strategies for Sustainable Urban Development and Urban-Rural Linkages, Research brief, March 2014, European Journal of Spatial Development.

17. Namperumal S, Taubenbo"ck H, Jain M (2011). Seamless urbanization and knotted city growth: Delhi metropolitan region. In: Proceedings real CORP 2011 Tagungsband, 18-20 May 2011. ISBN:978-3-9503110-1-3

18. Rahman, A. (2007). "Application of Remote Sensing and GIS Techniques for Urban Environmental Management and Sustainable Development of Delhi, India," Applied Remote Sensing for Urban Planning, Governance and Sustainability, Springer-Verlag Publishers, New York, 2007, pp. 165-197.

19. Seto, K., and Reenberg, A. (2014). Rethinking Global Land Use in an Urban Era. Strungmann Forum Reports, (eds.) vol. 14, Julia Lupp, series editor. Cambridge, MA: MIT Press.

20. United Nations (2019). World Population Prospects 2019: Highlights. United Nations. Available online at: https://population.un.org/wpp/Publications /Files/ WPP2019 Highlights.pdf.

21. United Nations (2018). Sustainable Development Goal 11-Make Cities and Human Settlements Inclusive, Safe, Resilient and Sustainable. Available online at: https://sustainabledevelopment.un.org/sdg11.

22. United Nations (2017). World Population Prospects. ww.un.org/ development/ desa/publications/world-population-prospects-the-2017-revision.html 